\title{
Turner 症候群に合併した成人大動脈縮窄症の 1 手術治験例
}

\author{
平山 亮 中 島昌 道* 小 柳 俊 哉
鈴
}

症例は 22 歳, 女性. 今までに特に自覚症状は認めていなかった. 平成 17 年 4 月の健診で高血圧症（上肢血 圧 180/112 mmHg）を指摘された。 心エコー，胸部造影 CT で上行大動脈拡大，大動脈縮窄，発達した肋間 動脈と側副血行路を認めた。低身長 $(137 \mathrm{~cm})$ と 2 年前からの無月経を認め, 婦人科で染色体検査を施行し Turner 症候群（45X0）と診断された．手術は胸骨正中切開でアプローチし上行大動脈-下行大動脈人工血 管バイパス術を施行した. 術後は高血圧の改善も見られ合併症もなく退院し社会復帰している. 日心外会誌 38 巻 3 号 : 226-228 (2009)

Keywords：Turner 症候群, 成人大動脈縮窄症, 上行大動脈-下行大動脈人工血管バイパス術

\begin{abstract}
A Case of Ascending-To-Descending Aorta Bypass Grafting for Coarctation of the Aorta Associated with Turner Syndrome

Ryo Hirayama, Masamichi Nakajima*, Toshiya Koyanagi, Ryusuke Suzuki and Toshiaki Watanabe (Department of Cardiovascular Surgery, Kumamoto Red Cross Hospital, Kumamoto, Japan, and Department of Cardiovascular Surgery, Kyoto First Red Cross Hospital*, Kyoto, Japan)

A 22-year-old woman without any serious distincted symptoms was found to have hypertension on a health examination. On further examinations, involving echocardiography and chest enhanced CT, showed dilatation of the ascending aorta, aortic coarctation, well-developed intercostal arteries and other collateral arteries. She was only $137 \mathrm{~cm}$ tall and weighed $52 \mathrm{~kg}$. Besides, she had not had menstruation for the past two years. Chromosomal studies revealed Turner syndrome. Left lateral thoracotomy was thought to have the risk of heavy bleeding from collateral arteries, therefore we chose ascending-todescending aorta bypass grafting through median sternotomy. She had an uncomplicated postoperative course. Here we report about operation in a adult case of coarctation of the aorta and discuss the usefulness of extraanatomical bypass grafting. Jpn. J. Cardiovasc. Surg. $38: 226-228$ (2009)
\end{abstract}

Turner 症候群は，X染色体異常により女子の性腺発生 異常・発育不全打よび種々の身体奇形を主徴候とする症候 群で, 発生頻度は約 2,500 人に 1 人と言わ狆ている。 心大 血管異常の合併は少なくとも $20 \%$ で, 特に大動脈縮窄症 （CoA）を高率に合併することが知られている.今回われ われは Turner 症候群に合併した成人大動脈縮窄症に対し て上行大動脈-下行大動脈人工血管バイパス術を施行し, 良好な結果を得たので報告する。

\section{症例}

症例 : 22 歳, 女性.

主訴：なし, 高血圧の精査.

既往歷: 2 年前からの続発性無月経.

現病歴：今までに特に自覚症状は認めなかった。大学入

2008 年 6 月 16 日受付, 2009 年 1 月 8 日採用

熊本赤十字病院心臓血管外科

干 861-8520 熊本市長嶺南 2-1-1

*京都第一赤十字病院心臓血管外科

本論文の要旨は, 第 39 回日本胸部外科学会九州地方会総会

（2006 年 7 月，北九州）に打いて発表した。
学時の健診で 180/112 mmHg の高血圧を認め精查目的で 当院を受診した。電図異常，心エコーで上行大動脈の拡 大を認めたため CT 施行した.上行大動脈拡大および CoA と診断された。 また, 無月経の精查では染色体検査 でTurner 症候群 (45XO) と診断された。

入院時現症: 身長 $137 \mathrm{~cm}$, 体重 $52 \mathrm{~kg}$, 脈拍 93/分, 血 圧上肢 $184 / 123 \mathrm{mmHg}$ (左右差なし), 下肢 141/94 $\mathrm{mmHg}$.

血液検查所見 : Estradiol（E2） $15 \mathrm{pg} / \mathrm{ml}$, FSH 56.5 $\mathrm{mIU} / \mathrm{ml}$, LH $28.6 \mathrm{mIU} / \mathrm{ml}$.

染色体検査所見 : 45 , XO.

胸部 X 線所見：心胸郭比 $48 \%$, 肺うっ血像なし. Rib notching を認めた。

心電図所見 : 洞調律, 軸偏位なし, III, ${ }_{\mathrm{a}} \mathrm{V}_{\mathrm{F}}, \mathrm{V}_{1 \sim 4}$ に陰 性 T波を認めた。

心エコー所見 : 大動脈二尖弁を認めたが, 弁逆流は認め なかった. 上行大動脈は約 $40 \mathrm{~mm}$ と拡大していた. 左室 壁運動は良好で, その他の心内合併奇形は認めなかった。

胸部 CT 所見 : 左鎖骨下動脈分岐部より末梢の大動脈は 


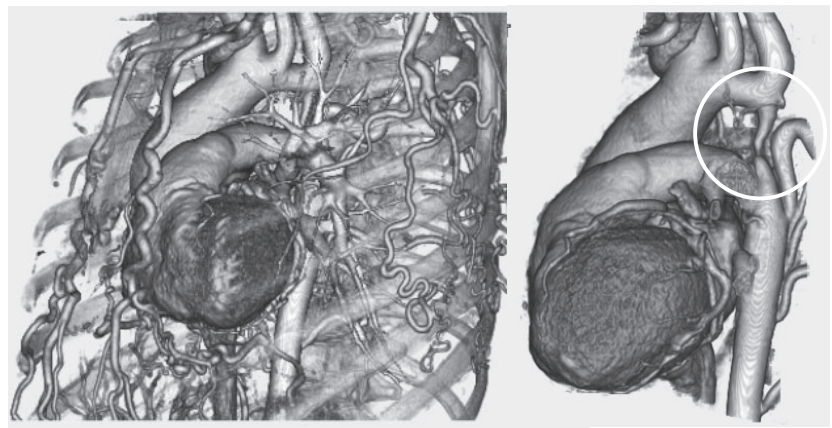

図 1 胸部 CT 所見

左鎖骨下動脈分岐部より未梢の大動脈は円錐状に狭小化し左肺 動脈レベルでの大動脈縮窄（○）を認める．両側内胸動脈，肋 間動脈が発達し側副血行路として未梢血管に流入している.

円錐状に狭小化し左肺動脈レベルでの大動脈縮窄を認め た. 両側内胸動脈, 肋間動脈が発達し側副血行路として未 梢血管に流入していた（困 1).

血管造影所見：上行大動脈は拡大し遠位弓部で狭窄して いた。両側内胸動脈は著明に拡大していた。

手術所見：左側開胸アプローチでは，発達した側副血行 路からの大量出血, 低身長, 肥満などによる視野確保困難 が予想されたため胸骨正中切開アプローチによる上行大動 脈一下行大動脈バイパス術を選択した。胸骨正中切開する と上行大動脈は拡大，弓部三分枝にも拡大を認めたが，弓 部大動脈は末梢側にかけて狭小化していた。体外循環は弓 部大動脈と右大腿動脈からの送血, 右心房からの脱血, 右 上肺静脈の venting で確立した。末梢側吻合を行うため, 左開胸，分離肺換気にて左肺を虚脱させ下行大動脈を観察 した. 縮窄部は左鎖骨下動脈分岐直後より索状で約 $5 \mathrm{~cm}$ の範囲であった。下行大動脈を遮断し縮窄部の末梢で端側 吻合を予定したが，大動脈壁が脆弱で容易に裂けるため縮 窄部で結愁切離し，下行大動脈に $20 \mathrm{~mm}$ の土血管 (INTERGARD ${ }^{\mathrm{TM}}$ ) を4-0 ポリプロピレンの連続縫合で 端々吻合した。次に，上行大動脈を弓部大動脈に近位部で 遮断し局所冷却と心筋保護液にて心停止とした。可能な限 り上行大動脈の末梢側で大動脈を切開し楕円形の吻合口を 作製し，人工血管は肺動脈の前面を誘導し端側吻合した (図 2). 遮断解除後は容易に心拍動を得た。体外循環から の離脱は特に問題なく，胸骨を閉鎖し手術を終了した。大 動脈遮断時間 103 分，体外循環時間 157 分であった。

術後経過は良好で術後 7 日目の上肢血圧は $128 / 76$ $\mathrm{mmHg}$ (左右差なし)，下肢血圧 $105 / 71 \mathrm{mmHg}$ と上肢高 血圧および上下肢血圧差は改善した。術後造影 CT 上でグ ラフト狭窄や吻合部仮性瘤を認めず，グラフトは良好に開 存していた。特に合併症もなく術後 14 日目に自宅退院, 術後 6 力月目の造影 CT でもグラフト周囲など異常所見は なかった。また，退院後 1 力月目から無月経に対して
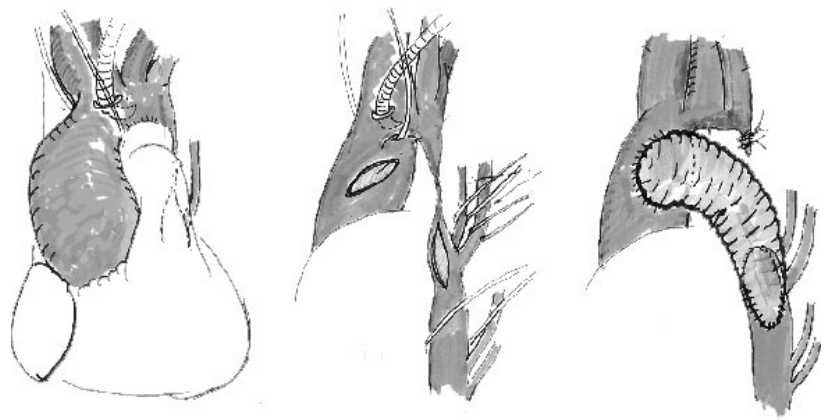

図 2 手術シェーマ

可能な限り上行大動脈末梢側で大動脈を切開し楕円形の吻合口 を作製し，人工血管は肺動脈の前面を誘導し端側吻合した。

Kaufmann 療法を開始した。

\section{考察}

Turner 症候群には心血管系異常の合併する頻度が高い ことはよく知られている ${ }^{11}$ 。とりわけ CoA は高頻度に合併 し ${ }^{2)}$, Nora らの報告では心血管系異常を合併する Turner 症候群 40 例のうち 11 例に CoA が存在した ${ }^{3)}$.

CoA は, 先天性心疾患の約 $6.5 \%$ といわれている. 非治 療の $90 \%$ が 50 歳に満たないうちに死亡する。原因は, 乳 幼児期は心不全が多く, 成人では感染性心内膜炎, 大動脈 破裂，脳出血などがある ${ }^{4)}$.

CoA の手術術式は, 縮窄切除·大動脈端々吻合術, patch angioplasty, 人工血管置換術, subclavian flap 法, 縮窄部切除後弓部拡大再建術や extraanatomical bypass な どがあげられる。成人 CoA の場合は，人工血管置換術か extraanatomical bypass の症例が報告されている ${ }^{4,5)}$. 今回 われわれは, 正中切開による上行大動脈-下行大動脈バイ パス術を選択した。著明に発達した側副血行路による大量 の出血, Turner 症候群に特徵的な低身長および肥満によ る視野確保の困難さのために，左側開胸アプローチでは手 術の危険性が高いと判断した ${ }^{6,7)}$. そこで本症例では，側 副血行路からの出血を回避すべく正中切開アプローチを行 い, 良好な視野を得るため弓部大動脈送血, 順行性心筋保 護による心停止下で心臓を脱転し下行大動脈の視野を展開 した. 縮窄後下行大動脈で切断し中枢側は断端を結紮処理 し末梢側へグラフトと端々吻合を行った。本症例では,

（1）拡大した上行大動脈の減圧と上半身に生じた高血圧 を解除すること, (2) 大動脈二尖弁によって今後大動脈 弁閉鎖不全が出現した際の再手術を考慮し，大動脈弓部に より近い位置に上行大動脈の端側吻合を行った ${ }^{8)}$.

術後の生理学的検査, 画像検査所見から extraanatomical bypass である上行大動脈-下行大動脈人工血管バイパ ス術で満足のいく結果を得られた。

Turner 症候群に合併した CoA 例では大動脈壁の脆弱性 
に伴い, 将来的に大動脈瘤や大動脈解離を合併しやすいと いう報告もあり, 今後も CT, MRI 等の画像検査で定期的 に経過観察する必要があると考える ${ }^{9,10)}$.

\section{結語}

Turner 症候群に合併した成人大動脈縮窄症に, 上行大 動脈-下行大動脈人工血管バイパス術を施行した 1 手術治 験例を経験したので報告した。

\section{文献}

1) Lemli, L. and Smith, D.W. : The XO syndrome. A study of the differential phenotype in 25 patients. J. Pediat. $63: 577-588$, 1963.

2) Haddad, H.M. and Wilkins, L. : Congenital anomoalies associated with gonadl aplasia. Pediatrics $23:$ 885-902, 1959.

3) Nora, J.J., Tores, F.G., Sinha, A.K. et al. : Characteristic cardiovascular anomalies of XO Turner syndrome, XX and $\mathrm{XY}$ phenotype and XO/XX Turner mosaic. Am. J. Cardiol. 25 :
639-641, 1970.

4) Kouchoukos, N.T., Blackstone, E.H., Doty, D.B. et al. : Kirklin/Barratt-Boyes Cardiac Surgery. 3rd ed., Churchill Livingstone, Utah, 2003, pp. 1315-1375.

5) Gatzoulis, M.A., Webb, G.D. and Daubeney, P.E.F. : Diagnosis and Management of Adult Congenital Heart Disease. Churchill Livingstone, London, 2003, pp. 253-264.

6）菊地千鶴男, 青見茂之, 高沢有史ほか：Turner 症候群に 合併した成人型大動脈縮窄症に対する 1 手術例. 日胸外会 誌 44 : 1175-1178, 1996.

7）太田喜義, 常本 実, 島田宗洋ほか: Turner 症候群に伴 った大動脈縮窄症. 胸部外科 $45:$ :11-414, 1992.

8）渡辺 孝, 弥政洋太郎, 阿部稔雄ほか: 大動脈縮窄症打よ び大動脈閉鎖不全症に右室流出路狭窄症を合併したター ナー症候群の 1 手術例. 臨胸外 $2: 853-860,1982$.

9) Ho, V.B., Bakalov, V.K., Cooly, M. et al. : Major vascular anomialies in Turner syndrome prevalence and magnetic resonance angiographic features. Circulation 110:16941700, 2004.

10) Sybert, V.P. : Cardiovascular malformations and complication in Turner Syndrome. J. Pediat. 101 (1) : E11, 1998. 